\title{
A review of wind energy literature: alternative technologies for Central America
}

\author{
Nahún Edgardo-Portillo1, a, Santos Arita-Portillo ${ }^{1, b}$, Jimy Martinez-Martinez $^{1, \mathrm{c}}$, and Cesar H Ortega-Jimenez ${ }^{1,2,3, \mathrm{~d}, \mathrm{e}, \mathrm{f}}$ \\ ${ }^{1}$ Universidad Nacional Autónoma de Honduras (UNAH), Ing. Mecánica, Honduras \\ ${ }^{2}$ Universidad de Sevilla, Doctorado GENI, Sevilla, Spain \\ ${ }^{3}$ Universidad Tecnológica Centroamericana (UNITEC), Facultad de Postgrado, Honduras \\ anahun.portillo@unah.hn, ${ }^{\mathrm{b}}$ srarita@unah.hn, ${ }^{\mathrm{c}} \mathrm{jimy} . \mathrm{martinez@unah.hn,}{ }^{\mathrm{d}}$ cortega@unah.edu.hn, ${ }^{\mathrm{e}} \mathrm{cortega@us.es,}{ }^{\mathrm{f}} \mathrm{cortegaj@unitec.edu}$
}

\begin{abstract}
Wind energy has proven to be one of the most viable sources of renewable energy. In this sense, although wind power generation systems have evolved considerably in size, capacity and design, it has not been possible to build an ideal system, due to the behaviour of the wind, which varies temporarily, being something uncontrollable that depends of its direction and affects the efficiency of a wind system. Specifically, this paper focuses on making a first literature review that identifies the best technologies that can be implemented in Central America (CA). Although the types of wind turbines most used in CA are three-blade horizontal axis, since they take advantage of the variability of the winds, this review shows there are other technologies in developed countries for obtaining kinetic energy, by means of vertical Rotors that can be implemented. The results obtained have practical implications in the adoption of alternative technologies for developing countries in CA.
\end{abstract}

\section{Introduction}

With the progressive depletion of fossil fuels together with climate change, the search for alternative sources of clean energy have increased greatly in recent years[1]. Some of them, such as wind, solar, biomass or geothermal energy are having a spectacular development[2]. Especially, wind energy has played a very important role in recent years, because its primary energy source, the wind, is a resource that exists to a greater or lesser extent anywhere on the planet, making it relatively easy to access it. anyone in the world[3]. The atmosphere is not uniform throughout its thickness. Because of the weight of the air, its lower layers, those that are close to the ground, are more compressed than the upper ones and are denser. In the lower layer is where the winds move, in the upper one it moves smoothly, but movements of ascent and descent are noted[4].

Specifically, according to the special report on the impacts of global warming issued by the IPCC in 2018, Central America (CA) has an increase in hurricane winds during the occurrence of hurricanes or tropical storms, and with a flow of fluid air during the summer season[5]. However, in the entire region there is no real study to determine the potential of both maritime and terrestrial winds. Regarding wind power generation, the problem is that the wind speed is not constant and, therefore, it is necessary to know its time evolution to estimate the useful energy of a wind turbine capable of delivering in a given period. Unfortunately, the measurements that are made for climatological purposes in the area in question, do not have, in general, the degree of detail required by certain wind projects.[6].

Thus, the main objective of this paper is to conduct a literature review that identifies recent research on new technologies in wind power generation turbines, which can be better implemented with respect to wind currents in CA. To answer the proposed objective, in the next section (2) we present the frame of reference and propositions. In Section 3 we explain the methodology used. Next, in Section 4 we discuss the results. Finally, in Section 5 we give the conclusions of the paper.

\section{Conceptual Framework and Proposition}

CA has enormous potential to become a world leader in renewable energy. In relation to its energy, the wind has been used to produce energy at the scale of public services since the 1990s. The total installed capacity of wind energy in the region reached 298 megawatts in 2011 and just a little more $38 \%$ of the wind capacity was installed in 2010 . In 2011, CA produced 738 gigawatt-hours of electricity based on wind, which represents $1.7 \%$ of the generation in the entire region[7].

On the one hand, the three countries, Costa Rica, Honduras, Nicaragua, are preparing new facilities[8]. On the other hand, Panama, an ambitious newcomer, has licensed more than 850 megawatts of wind capacity, equivalent to a staggering $37 \%$ of installed generation capacity in 2011[7]. Below, we show the characterization

Corresponding author: ${ }^{\mathrm{d}}$ cortega@unah.edu.hn 
of the generation potential by wind energy in CA, as shown in the wind map shows the geographical areas with the greatest potential for wind generation in the countries of its Northern Triangle (Honduras, Guatemala and El Salvador), noting that there is a set of classifications given, that for wind energy densities above $400 \mathrm{~W} / \mathrm{m} 2$ there is the possibility of implementing applications of profitable scale [7].

The new energy models of CA and the world in general are demanding a type of renewable energy as we consider wind energy[9]. Although it is trying to implement an energy model in all regions of the world, the possibility of doing so is being affected by the ability of the wind to promote the movement of the turbine in some areas and the generation of electric power, this is known as the wind potential of each region[10]. From a practical point of view, the energy content of the wind is what you want to take advantage of. The kinetic energy per unit time of an air mass that moves is determined by the so-called "Law of the Cube"[2].

$$
P=\frac{1}{2} * \rho * A * V^{3}(1)
$$

Being: $\mathrm{P}=$ Energy per unit of time (W); $\mathrm{A}=$ intercepted area $\left(\mathrm{m}^{3}\right) ; \rho=$ air density $\left(\frac{\mathrm{kg}}{\mathrm{m}^{3}}\right) ; \mathrm{V}$ wind speed. $\left(\frac{m}{s}\right)$.Energy is defined as the power during a specific period of operation of the wind machine. In the specific case of aerogeneration, it is sought to transform this energy into mechanical energy through a rotor, which in turn will end up transforming itself into electrical energy, by means of a generator, for its storage or directly for its consumption. However, due to variations in speed magnitude, it is convenient to speak in terms of energy for certain periods of time[7].

To extract from the wind, the greatest possible amount of energy, the characteristics of the apparatus and the environmental conditions must be combined properly, because where there is a higher wind flow, a type of wind turbine must be located[11].The amount of energy that the wind has varies with the change in the average wind speed. In the case of wind turbines, the energy of the wind is used; thus, if we double the wind speed, we will have twice more cylindrical portions of wind through the rotor every second where each of those portions contains four times more energy, and the power from the wind increases by a factor of eight [12].

\subsection{Extraction of power from wind currents}

Already with the input and output variables of a wind turbine established; it is possible to arrive at an equation relating these variables. The relationship between power and wind speed is given in equation (1), mentioned above. What we need now is how much of this power that the wind has is taken advantage of by the wind turbine[12], after making several calculations the following expressions are obtained[2].

$$
\begin{aligned}
& P=\frac{1}{2} * \rho * A * V^{3} * C_{P}(2) \\
& C_{P}=\frac{\left(1+\frac{V_{0}}{V}\right)+\left(1+\left(\frac{V_{0}}{V}\right)^{2}\right)}{2}
\end{aligned}
$$

$V$ being the air entry speed and $V_{0}$ the exit velocity. The $C_{p}$ is the fraction of the wind power that is captured by the rotor blades, which has a theoretical maximum value of 0.59 . It is also referred to as the rotor power coefficient or rotor efficiency. In practical methods the maximum $C_{p}$ that can be obtained is between 0.4 and 0.5 for the high speed turbines, and between 0.2 and 0.4 for the slowest ones[13]. From equation 3 , the rotor power coefficient is determined by the effective area of the rotor blades, the wind speed of in and out. Therefore, the power output of the turbine can be varied by changing the wind flow conditions in the rotor system, which forms the basis of wind turbine control today[2].

\subsection{Variable speed and constant speed}

Considering the rotational speed, wind turbines can be divided into two types: units of fixed rotational speed and variable rotational speed. In the machines of constant speed, the electrical generator is connected directly to the infinite bar and always rotates at the same angular velocity, which is a submultiple of the network frequency. Synchronous generators are usually used, although asynchronous generators can also be used. In the case of the latter, the speed of rotation will vary slightly depending on the torque that is imposed on the shaft. On variable speed machines. The electric generator is connected to the infinite bar through a power electronics stage, which allows to vary the speed of the generator regardless of the value of the network frequency[14].Variations in wind speed produce variations in the power coefficient unless the generator speed (or the pitch angle of the blades) is varied to keep the ratio $\lambda$ constant, and Therefore, the power coefficient. Because the curve of the power coefficient presents a maximum for a certain value of $\lambda$ (maximum power transmission), the best use of the wind generator occurs when working at that point[15]. Obviously, in wind generators of variable speed, the rotation speed of the blades can be modified to work on the optimum value of the speed ratio $\lambda$ or, at least, close to its optimum value. In this way, the variable speed wind generator can capture up to $10 \%$ more average annual energy than the constant speed. However, a variable speed wind turbine cannot always work at the point of maximum power transmission, since, for wind speeds higher than an assigned value, the nominal power of the generator cannot be exceeded and the generator must work in a power regime Constant[2].

\subsection{Types of wind}

The knowledge of the general winds is not enough for a correct use and location of machines driven by the wind, as there are factors that modify the general regime and that should be known and taken into account when carrying out a project of this type[16]. The Bjerknes axiom indicates the movement or direction of rotation of the wind: When the pressure gradient and the temperature gradient have a different direction, there is a circulation of air from the shortest path from the pressure gradient to the gradient. temperature. In general, the vertical displacements of the 
air are small in relation to the horizontal displacements, so it can be considered that the direction of the displacement of the wind is substantially horizontal and is determined and referred to by the angle that it forms with respect to a fixed direction, which is the geographical North[3], therefore the general winds, like the synoptics, are linked to the atmospheric circulation and maintain the same characteristics over large tracts of land[15]. The synoptic wind blows practically in the horizontal, which allows to outline its movement by a vector oriented in the direction towards which it blows and whose origin is in the observation place. Regional winds are also governed by displacements on the synoptic scale of air masses. Its characteristics are determined according to given and very precise meteorological situations, such as the isobaric configuration and the position of the fronts, taking into account also, for any place, the regional geographical conditions as well as the local ones[10].

\subsection{Parameters of speed by wind turbines}

Table 1 shows the wind turbine generator system with four different types of wind turbines to suit different on-site wind conditions, designated with classes by increasing numbers corresponding to reductions in wind speed[17]. Here, one can see the different types of rotors and their characteristics. Because each rotor is designed according to the characteristics of the area of application, the slow machines are those in which the ratio between the speed of the tip of the blade and the wind speed is less than 2, while in the machines Fast is in Superior to 4. The most successful vertical axis turbines are the Darrieus rotors. The most attractive feature of this type of turbine is that the generator and transmission devices are located on the ground. In addition, it is capable of capturing wind energy from any direction of the wind without the need to nod[18]. Wind turbines with two blades have the advantage of the light weight supported by the structure of the tower, the light construction that allows to build, which means lower costs. Visual aesthetics and noise levels are less important in places where aesthetics do not matter so much, this may be the location of wind turbines where there is not a high level of population, such as in the middle of the sea [19].

\subsection{Framework proposition}

From above, we have identified technologies not applied in CA: (1) horizontal axis: Dutch and American multi-blade; and (2) vertical axis: Savonius and Darrieus that are implemented in the main wind energy producing countries, which are mostly developed at sea. In addition, considering the explained wind context of CA, we propose the following proposition: Wind technologies not yet implemented in CA, may be applicable, according to their wind potential.

Table 1. Speed parameters for wind turbine.

\begin{tabular}{|c|c|c|c|c|c|}
\hline Axis & \multicolumn{3}{|c|}{ HORIZONTAL } & \multicolumn{2}{|c|}{ VERTICAL } \\
\hline Rotor type & Dutch & $\begin{array}{l}\text { American } \\
\text { multi-blade }\end{array}$ & $\begin{array}{l}\text { Aerodynamic profile } \\
\text { (propellers) }\end{array}$ & Savonius & Darrieus \\
\hline Maximum performance & 0.17 & 0.15 & 0.47 & 0.3 & 0.35 \\
\hline Characteristics & $\begin{array}{c}-30-40[\mathrm{~kW}] \\
\text { - High starting } \\
\text { torque } \\
\text { - Average } \\
\text { speed } \\
-0,-4 \text { blades }\end{array}$ & $\begin{array}{c}\text {-0.4-6 [kW] } \\
\text { - High starting } \\
\text { torque } \\
\text { - Low speeds } \\
\text { - Lost } \\
\text { - } 12-15 \text { blades }\end{array}$ & $\begin{array}{c}-0.5-3.200[\mathrm{~kW}] \\
\text { - Low starting torque } \\
\text { - High speeds } \\
\text { - High performance } \\
\text {-1 to } 3 \text { blades }\end{array}$ & $\begin{array}{c}-0-1.5[\mathrm{~kW}] \\
\text { - No need to be } \\
\text { oriented } \\
\text { - High starting } \\
\text { torque } \\
\text { - Low speeds } \\
-2 \text { to } 4 \text { blades }\end{array}$ & $\begin{array}{l}-5-500[\mathrm{~kW}] \\
\text {-Does not need } \\
\text { to be oriented } \\
\text {-Does not start } \\
\text { alone } \\
\text { - High speeds } \\
-2 \text { to } 4 \text { blades }\end{array}$ \\
\hline
\end{tabular}

additionally use Research Gate, Academia, Google Scholar as complement.

\section{Methodology of the research}

The methods used for the literature review of this paper is next described. The inclusion and exclusion criteria from Table 2 were used to include and exclude literature found in the database, where some supposedly relevant documents from the specialized literature did not add value to our research topic. The search strategy served as a guide to carry out the research. Thus, after defining the objective in the introduction, we started with the formulation of a search strategy using keywords for the subject as in Table 2. The papers and documents were searched in the scientific database on the web as seen in the table 2 .

Table 2 sums up the search methods for the literature review and information gathering to achieve the objective of this paper, through databases such as Scopus, EBSCOhost, ScienceDirect, through keywords, years of publication and the validation of the results. Besides, we
Table 2. Methodology: Review of literature.

\begin{tabular}{|l|l|}
\hline Bibliographic search & $\begin{array}{l}\text { Scopus, EBSCOhost, Science } \\
\text { Direct. }\end{array}$ \\
\hline $\begin{array}{l}\text { Define conceptual } \\
\text { limits. }\end{array}$ & Extremely new technologies \\
\hline Language. & Spanish, English \\
\hline Applied search. & $\begin{array}{l}\text { Information related to the } \\
\text { subject }\end{array}$ \\
\hline Keywords. & $\begin{array}{l}\text { Wind energy, Wind, Wind } \\
\text { turbine }\end{array}$ \\
\hline Period of publication. & From 2009 to 2018 \\
\hline $\begin{array}{l}\text { Validating search } \\
\text { results }\end{array}$ & $\begin{array}{l}\text { Comparison between } \\
\text { researchers. Reviewing papers } \\
\text { by all coauthors }\end{array}$ \\
\hline
\end{tabular}




\section{Discussion of the review}

To develop this review, work began on 14 papers related to the wind potential in Central America (CA) and some of the technologies used by developed countries that could be implemented in the countries in CA (Table 1). Then, using the criteria from the previous section, nine papers were excluded. With the remaining five, we consider that to implement the types of wind turbines in question, we must consider the wind speed parameters for the turbine class in wind turbines. Thus, the existing data on wind resources in CA (both the amount of wind and its speed) are largely generic and give few details about specific sites. One of the most widely cited sources of renewable energy potential in the region is the Solar and Wind Energy Resource Assessment (SWERA), which provides resource maps for 13 sites, including $\mathrm{CA}$ in general and evaluations for complete countries in the case of El Salvador, Honduras, Guatemala and Nicaragua. These data sets, as well as maps and analysis tools, are used by policy makers, developers, investors, educators, utility companies and consumers.

According to the SWERA, the mapped region of CA (Belize, El Salvador, Guatemala, Honduras and Nicaragua) contains some 12,969 square kilometers with good to excellent wind resource potential, representing $3.3 \%$ of the total area. Using a conservative assumption of 5 megawatts per square kilometer, these areas would support almost 65,000 megawatts of possible installed wind capacity. The types of wind turbines with new technology that have not yet been implemented in the countries in CA (Table 1). For the developing countries, most of the magazines indicate that Asia and Latin America continue to have very weak wind energy markets, mainly because the governments of these countries do not have the will to promote renewable energy projects. they prefer to go to the credit agencies that provide financing for projects based on fossil fuels. That is why in the literature review of Table 3 , emphasis is placed on linking it to the countries of the region[7].

Table 3. Review of wind technologies.

\begin{tabular}{|l|l|l|l|}
\hline Paper name & Year & Technology & Source \\
\hline $\begin{array}{l}\text { The } \\
\text { generation of } \\
\text { wind electric } \\
\text { power. }\end{array}$ & 2015 & $\begin{array}{l}\text { Study of the wind by } \\
\text { means of mathematical } \\
\text { and physical equations. }\end{array}$ & {$[2]$} \\
\hline $\begin{array}{l}\text { Large-scale } \\
\text { wind energy. }\end{array}$ & 2014 & $\begin{array}{l}\text { New development of } \\
\text { wind turbines. }\end{array}$ & {$[19]$} \\
\hline $\begin{array}{l}\text { Evaluation of } \\
\text { control } \\
\text { strategy of } \\
\text { high-power } \\
\text { wind } \\
\text { turbines. }\end{array}$ & 2012 & $\begin{array}{l}\text { Different types of wind } \\
\text { turbines }\end{array}$ & {$[18]$} \\
\hline $\begin{array}{l}\text { Renewable } \\
\text { energy. }\end{array}$ & 2015 & $\begin{array}{l}\text { Renewable energies: } \\
\text { Wind energy. }\end{array}$ & {$[11]$} \\
\hline $\begin{array}{l}\text { CA } \\
\text { Renewable } \\
\text { Energy }\end{array}$ & 2017 & Wind potential. & {$[7]$} \\
\hline
\end{tabular}

From Table 3, a literature review of the most important papers was made. Firstly, [2] studies wind through the mathematical equations shown above, which serves to calculate the wind potential that is used by the wind turbine in addition to help us decide what type of technology to recommend for implementation. Secondly, the authors, [19] identifies the different wind turbines use for the generation of wind energy, stating that each type of wind turbine must be implemented according to the wind potential in one place determined. In our case, it is important to know the type of technologies that can be applied in CA to take better advantage of the wind flow.

[18] searches the different types of turbine applied in specific areas, where they found that the technology implemented to obtain wind potential in $\mathrm{CA}$ is the three-blade horizontal. [11] obtains information on the most relevant technologies for obtaining wind potential, which are divided according to rotor axes: horizontal \& vertical. The vertical axis is not being implemented in CA. Finally, [7] informs about the wind potential in CA and helped us to find that the technologies that are not yet applied in CA are the vertical axis wind turbines. According to this, we can accept the proposition that such type of vertical axis technology can be implemented in the region.

\section{Conclusions and recommendations}

This paper offers a comparative literary review with respect to the technology and methods of vertical axis wind turbines (Savonius and Darrieus), from the main wind power generating countries, which can be implemented in $\mathrm{CA}$, given that only the three-blade horizontal axis wind turbines (Dutch, American multi-blade, Aerodynamic) are currently being used in the region.

On the other hand, according to Word Watch Institute, in its report on The Road to the Future for Renewable Energy in CA, to develop a wind energy project is estimated an approximate cost of $\$ 36.5$ million dollars to generate electricity for about 30 years. It would have a capacity to produce about 13 megawatts. The cost of $\mathrm{kWh}$ would be around $0.16 \$$, which according to the price and the economic conditions of the area, it may require subsidies from developed countries, so that their local inhabitants can pay for it. One of the limitations of the study is that we focus on wind turbine technologies that involve the aerodynamic, structural improvement of the blades in the monitoring system, among others, that have not yet been implemented in CA. This presents an opportunity for future studies on Wind Potential, to identify other wind technologies that can be implemented in the area in question. This paper presents a first literature review on wind potential in $\mathrm{CA}$, showing practical implications of the implementation of new wind technologies in the area.

\section{Acknowledgments}

The authors wish to acknowledge the support of UNAH. 


\section{References}

[1] C. R. Villalobos, "Desarrollo fuentes energías limpias en Costa Rica.," 2014.

[2] R. A. Núñez, "La Generación de Energía Eléctrica por el Poder del Viento," Academia, pp. 1-9, 2015.

[3] P. Fernández Díez, "Fundamentos aerodinámicos," Energía eólica, pp. 1-135, 2008.

[4] W. K. Al-Nassar, S. Neelamani, K. A. Al-Salem, and H. A. Al-Dashti, "Feasibility of offshore wind energy as an alternative source for the state of Kuwait," Energy, vol. 169, pp. 783-796, Feb. 2019.

[5] IPCC, “Cambio climático 2007: Informe de sintesis”. ISBN 92-9169-322-7. 2014.

[6] F. Ferreira, "OLADE - Contribución al Desarrollo de Energías Renovables," 2014.

[7] A. Dolezal, A. M. Majano, A. Ochs, and P. y Ramón, "La Ruta hacia el Futuro para la Energía Renovable en Centroamérica\&nbsp;", p. 93, 2013.

[8] N. Apergis and J. E. Payne, "The renewable energy consumption-growth nexus in Central America," Appl. Energy, vol. 88, no. 1, pp. 343-347, Jan. 2011.

[9] F. J. Domínguez, B. Bajo, L. Dirección De Los Doctores, M. Molina Ibáñez, M. Ángel, and T. Vinuesa, "La Integración Territorial De Las Energías Renovables Presentada Para Optar Al Grado De Doctor.," 2012.

[10] M. G. M. Briones-salas, "Revista Mexicana de Biodiversidad Composición y actividad de la comunidad de murciélagos artropodívoros en parques eólicos del trópico mexicano," Enfermería Univ., vol. 88, no. 4, pp. 888-898, 2017.

[11] M. Antolínez, "Energías renovables: marco conceptual de la energía eólica, su importancia, tipos de turbinas eólicas, curvas de rendimiento, potencial de energía y densidad, eficiencia de la turbina, y límite de Betz mediante un proceso de recopilación de información," Univ. Bogotá Jorge Tadeo Lozano, pp. 1-13, 2015.

[12] I. Kubiszewski, C. J. Cleveland, and P. K. Endres, "Meta-analysis of net energy return for wind power systems," Renew. Energy, vol. 35, no. 1, pp. 218225, Jan. 2010.

[13] M. R. Patel, B. Raton, L. New, Y. Washington, and D. C. C. Press, Wind and Solar Power Systems Library of Congress Cataloging-in-Publication Data. .

[14] L. M. Lostaunau, "Energía Eólica: Alternativa Energética Viable," Fac. Ing. Electrónica y Eléctrica, Univ. Nac. Mayor San Marcos, pp. 3235, 2015.

[15] Y. G. Canché Ventura, I. de J. May-Cen, E. del J. Tamayo Loeza, E. Novelo Cetina, and R. S. Mezquita Martínez, “Análisis comparativo de aerogeneradores utilizando datos de viento," Rev. del Cent. Grad. e Investig., vol. 33, no. 70, pp. 7480,2018

[16] V. Beyá-Marshall, J. Herrera, F. Santibáñez, and T. Fichet, "Microclimate modification under the effect of stationary and portable wind machines," Agric. For. Meteorol., vol. 269-270, pp. 351-363, May 2019.

[17] R. P. F. M. González-longatt, "Normativa IEC 64100-1 : Modelado del Viento en condiciones Normales Parte I Índice General,” 2008.

[18] C. Conca de la Asuncion, "Evaluation of control strategies of high power wind turbines," Universiad Politecnica de Valencia, 2012.

[19] M. Dahlgren, H. Frank, M. Leijon, F. Owman, and L. Walfridsson, "Windformer, energía eólica a gran escala," ABB Rev., vol. 3, no. January 2000, 2000. 